DOI: https://doi.org/10.24144/2409-6857.2021.1(57).59-67

УДК 658:351.863

Пойда-Носик Н.Н., Черленяк I.I.

\title{
УПРАВЛІННЯ ФІНАНСОВОЮ БЕЗПЕКОЮ НА МАКРО- ТА МІКРОРІВНЯХ: ТЕОРЕТИКО-МЕТОДОЛОГІЧНІ ЗАСАДИ
}

У статті розкрито зміст управління фінансовою безпекою на макро- та мікрорівнях. Представлено результати порівняння основних компонентів механізму державної та корпоративної систем управління фінансовою безпекою. Наголошено на важливості та розкрито зміст адаптивного управління з точки зору властивості адаптивних систем, яка полягає у досягненні мети управління в умовах недетермінованого зовнішнього середовища. Виділено інструменти адаптивного управління. Представлено процес управління фінансовою безпекою з урахуванням принципу адаптивності. Виділено проблеми впровадження науково обтрунтованих моделей у практику вітчизняних корпоративних підприємств.

Ключові слова: фінансова безпека; державна та корпоративна системи управління фінансовою безпекою; механізм забезпечення фінансової безпеки; принциип адаптивності.

Постановка проблеми. В умовах нестабільності та суперечливості трансформаційних процесів, посилення глобальних кризових явищ, зростання рівня невизначеності та впливу фінансових ризиків на фінансову систему країни, одним 3 основних завдань науки $\mathrm{i}$ практики стає розробка ефективної моделі системи управління фінансовою безпекою як на макро-, так i на мікрорівнях. Фінансово-економічна криза 20082013 років, пандемія 2020 року виявила істотні проблеми багатьох країн Європи: ріст боргів національних економік; недостатність та неефективність регулятивних процедур i процесів; відсутність системного підходу до вирішення цих проблем.

Різноманітність ризиків і загроз фінансового середовища для економічних агентів, варіативність інтересів різних груп учасників фінансових відносин потребують виявлення причинно-наслідкових зв'язків, що вимагає застосування системного підходу як на рівні держави, так і на рівні суб'єктів господарювання. У зв'язку 3 цим важливим $\epsilon$ всебічне наукове обгрунтування механізмів управління фінансовою безпекою на різних рівнях

(Пойда-Носик Н.Н, к.е.н., проф., професор кафедри фінансів і банківської справи ДВНЗ «Ужгородський національний університет», м.Ужгород, e-mail: nina.nosyk@uzhnu.edu.ua

Черленяк I.I., доктор наук 3 державного управління, проф., професор кафедри бізнесадміністрування, маркетингу та менеджменту ДВН3 «Ужгородський національний університет», м.Ужгород, e-mail: ivan.cherlenjak@uzhnu.edu.ua фінансових відносин, 3 метою вибору та обгрунтування заходів, які будуть протидіяти появі негативних наслідків ризиків і загроз та сприяти досягненню фінансової рівноваги суб'єктів фінансових відносин i створювати фінансовий потенціал розвитку на довгострокову перспективу.

Аналіз останніх досліджень і публікацій. Слід відзначити, що питання управління фінансовою безпекою є об' єктом наукового інтересу багатьох вітчизняних та зарубіжних вчених. У теоретико-прикладному аспекті значний внесок у дослідження проблематики фінансової безпеки на рівні держави зробили праці таких науковців, як О. Барановський, М. Срмошенко, А. Сухоруков, О. Ладюк, Б. Губський, Я. Жаліло, Г. ПастернакТаранушенко та інші. Проблемам забезпечення фінансової безпеки на мікрорівні присвячені праці таких вітчизняних науковців, як O. Ареф'єва, І. Бланк, К. Горячева, Т. Загорельска, І. Журавлева, Т. Кузенко, О. Кириченко, О. Пластун, Ю. Кім, М. Погосова, В. Франчук, І.Шульга та ін. Високо оцінюючи їх вклад у вирішення теоретичних і практичних аспектів щодо управління фінансовою безпекою на різних рівнях фінансових відносин, потрібно вказати на необхідність подальшого розвитку теоретичної бази з даної тематики. На сьогодні $є$ цілий ряд невирішених проблем у цій сфері, зокрема, це чіткість ідентифікації основних компонентів механізму управління фінансовою безпекою на різних рівнях фінансових відносин та врахування принципу адаптивності при побудові таких систем управління.

Мета статті полягас у дослідженні компонентів механізму державної та корпоративної систем управління фінансовою безпекою та побудові процесу управління 3 
урахуванням принципу адаптивності до мінливого середовища.

Опис основного матеріалу дослідження. Досліджуючи поняття «управління фінансовою безпекою» через призму різноманітних підходів до розуміння суті управління, було виявлено, що часто науковці не розмежовують «механізм управління фінансовою безпекою» $\mathrm{i}$ «механізм забезпечення фінансової безпеки». Виходячи із розуміння процесу управління як цілеспрямованого впливу на об'єкт чи систему для збереження їхньої стійкості або переведення з одного стану в інший, «механізм управління» доречно розглядати як спосіб впливу суб'єкту на об'єкт за допомогою різних засобів, а «механізм забезпечення» сукупність заходів по створенню надійних умов гарантування захисту від небезпеки. У зв’язку з цим у праці [1] нами було визначено поняття «управління фінансовою безпекою» як систему принципів i методів розробки i реалізації управлінських рішень, пов'язаних із забезпеченням захисту пріоритетних фінансових інтересів суб'єкта фінансових відносин від зовнішніх і внутрішніх загроз та спрямованих на створення умов для стабільного розвитку у майбутньому періоді.

Функціонування системи управління фінансовою безпекою повинен передбачати розробку комплексу особливих методів і засобів, застосування специфічних механізмів та існування відповідної системи спеціальних органів управління. Важливою складовою системи управління фінансовою безпекою $\epsilon$ механізм управління фінансовою безпекою, основними компонентами якого $є$ : мета (цілі), суб'єкт, об'єкт управління, завдання, критерії, принципи, функції, методи, важелі, інструменти,. Ці компоненти суттєво відрізняються на рівні держави та підприємств. Результати авторського дослідження порівняння основних компонентів механізму державної та корпоративної систем управління фінансовою безпекою представлено в табл.1.

\section{Порів}

Порівняння компонентів механізму державної та корпоративної систем управління фінансовою безпекою*

\begin{tabular}{|c|c|c|}
\hline Компоненти & $\begin{array}{c}\text { Державна система } \\
\text { управління ФБ }\end{array}$ & $\begin{array}{c}\text { Корпоративна система } \\
\text { управління ФБ }\end{array}$ \\
\hline 1 & 2 & 3 \\
\hline $\begin{array}{l}\text { Мета } \\
\text { управління }\end{array}$ & 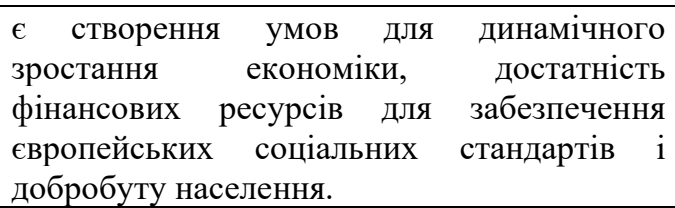 & $\begin{array}{l}\text { гарантія стабільного фінансового стану } \\
\text { підприємства на сучасному етапі часу та } \\
\text { високого фінансового потенціалу розвитку у } \\
\text { майбутньому. }\end{array}$ \\
\hline $\begin{array}{l}\text { Суб'єкт } \\
\text { управління }\end{array}$ & $\begin{array}{l}\text { Міжвідомча комісія з питань фінансової } \\
\text { безпеки при РНБО, КМУ, Рахункова палата, } \\
\text { Міністерство фінансів, НБУ, Державна } \\
\text { фіскальна служба України ті ін. }\end{array}$ & $\begin{array}{l}\text { Внутрішні суб 'єкти: власник, фінансовий } \\
\text { директор, керівник служби (відділу) } \\
\text { фінансово-економічної безпеки, керівники } \\
\text { структурних підрозділів. } \\
\text { Зовнішні суб'єкти: партнери } 3 \text { бізнесу, } \\
\text { правоохоронні органи, державні органи } \\
\text { влади, страхові організації, консалтингові } \\
\text { фірми, ЗМІ. }\end{array}$ \\
\hline $\begin{array}{l}\text { Об'єкт } \\
\text { управління }\end{array}$ & $\begin{array}{llr}\text { Державні фінанси, } & \text { бюджетний } \\
\text { дефіцит/профіцит, державний } & \text { борг, обсяг } \\
\text { іноземних інвестицій, } & \text { податкові } \\
\text { надходження, фінансовий стан банківської } \\
\text { системи й окремих банківських установ, } \\
\text { інші параметри функціональних складових } \\
\text { фінансової безпеки держави. }\end{array}$ & $\begin{array}{l}\text { Параметри фінансово-економічної діяльності } \\
\text { підприємства (фінансові ресурси, інвестиції, } \\
\text { структура капіталу, фінансові ризики, } \\
\text { грошові потоки тощо); інформація; } \\
\text { персонал. }\end{array}$ \\
\hline Завдання & $\begin{array}{l}\text { - формування системи пріоритетних } \\
\text { фінансових інтересів, що потребують } \\
\text { захист з огляду на мету управління ФБ; } \\
\text { - ідентифікація і прогнозування загроз } \\
\text { зовнішнього і внутрішнього середовища } \\
\text { функціонування суб’єкта господарювання } \\
\text { його фінансовим інтересам; }\end{array}$ & $\begin{array}{l}\text { - аналітична обробка інформації про досвід } \\
\text { щодо забезпечення ФБ ін підприємств і } \\
\text { аналіз конкурентних переваг; } \\
\text { - збирання, накопичення, аналітична } \\
\text { обробка інформації, що характеризує } \\
\text { фінансовий стан підприємства та } \\
\text { виділення загроз; } \\
\text { - стратегічне планування забезпечення ФБ; }\end{array}$ \\
\hline
\end{tabular}




\section{Продовження таблиці 1}

\begin{tabular}{|c|c|c|}
\hline & 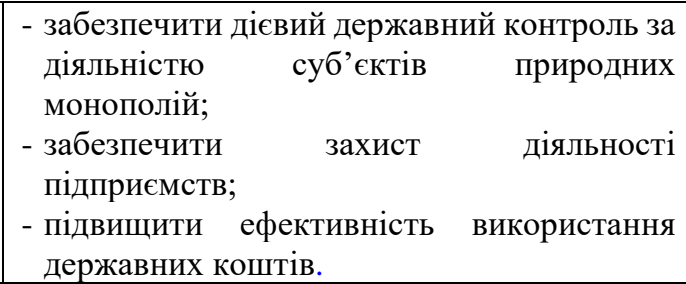 & $\begin{array}{l}\text { - постійний моніторинг і аналіз умов, } \\
\text { чинників, загроз та індикаторів ФБ; } \\
\text { - розробка та здійснення заходів щодо } \\
\text { підтримання ФБ на належному рівні. }\end{array}$ \\
\hline Kритерї & $\begin{array}{l}\text { - ефективність використання ресурсного } \\
\text { потенціалу і можливостей його розвитку; } \\
\text { - конкурентоспроможність економіки, } \\
\text { цілісність території та економіч- } \\
\text { ного простору; } \\
\text { - незалежність і можливість протистояти } \\
\text { зовнішнім загрозам; } \\
\text { - соціальна стабільність та наявність умов } \\
\text { відведення і розв'язання соціальних } \\
\text { конфліктів. }\end{array}$ & $\begin{array}{l}\text { - значення індикаторів, що кількісно } \\
\text { визначають стабільність фінансового } \\
\text { стану, здатність до розвитку та рівень } \\
\text { фінансових ризиків; } \\
\text {-відсутність корпоративних конфліктів та } \\
\text { ступінь гармонізації фінансових інтересів. }\end{array}$ \\
\hline Принцципи & 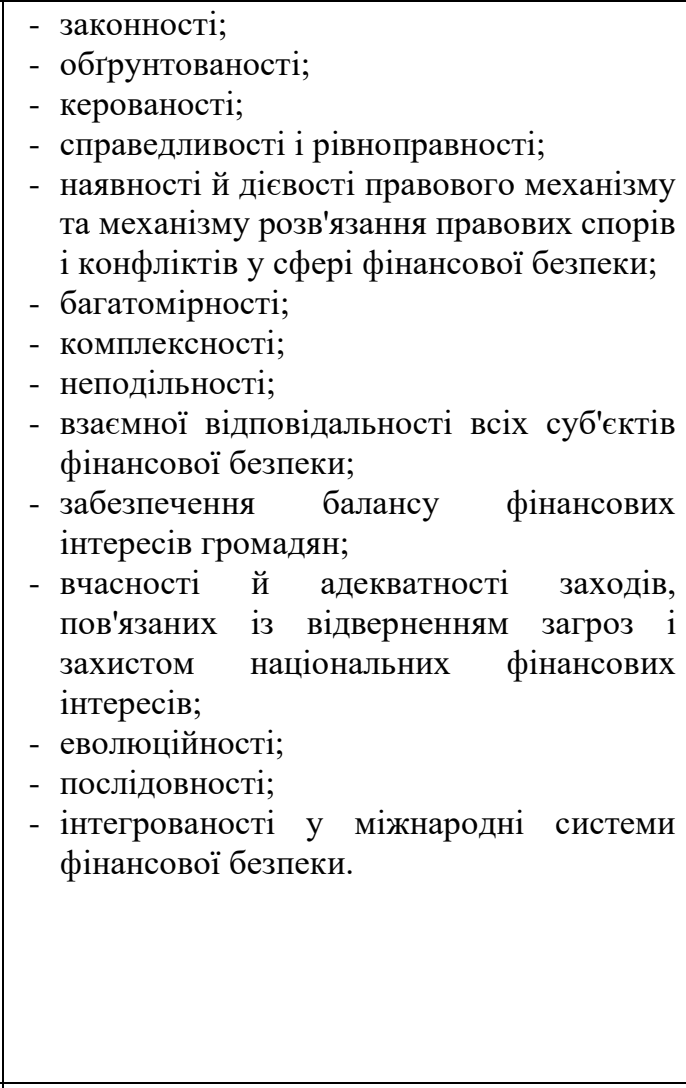 & $\begin{array}{l}\text { - системність побудови; } \\
\text { - інтегрованість із загальною системою } \\
\text { менеджменту; } \\
\text { - інтегрованість із системою управління } \\
\text { ЕБП; } \\
\text { - спрямованість на стратегічні цілі } \\
\text { фінансово-економічного розвитку } \\
\text { підприємства; } \\
\text { - об’єктивність; } \\
\text { - комплексний характер управлінських } \\
\text { рішень; } \\
\text { - безперервність; } \\
\text { - оперативність та динамічність } \\
\text { управління; } \\
\text { - варіативність підходів до розробки } \\
\text { окремих управлінських рішень; } \\
\text { - принцип неперервності моніторингу } \\
\text { зовнішнього середовища підприємства; } \\
\text { - адекватність реагування на окремі } \\
\text { загрози фінансовим інтересам; } \\
\text { - гнучкість управління; } \\
\text { - ефективність управлінських рішень, що } \\
\text { приймаються; } \\
\text { - законність управлінських рішень; } \\
\text { - стимулювання та відповідальність } \\
\text { персоналу і керівництва за стан } \\
\text { фінансової безпеки підприємства. } \\
\end{array}$ \\
\hline Функиії & $\begin{array}{ll}\text { - } & \text { планування і прогнозування; } \\
\text { - } & \text { облік і контроль; } \\
\text { - } & \text { організація і регулювання; } \\
\text { - } & \text { мотивація та стимулювання. }\end{array}$ & $\begin{array}{l}\text { - аналіз рівня фінансово-економічної } \\
\text { безпеки підприємства; } \\
\text { - постійний моніторинг і аналіз умов, } \\
\text { чинників, загроз та індикаторів ФБ; } \\
\text { - планування комплексу заходів для } \\
\text { забезпечення фінансово-економічної } \\
\text { безпеки підприємства. } \\
\text { - мотивація прийняття ефективних } \\
\text { управлінських рішень щодо забезпечення } \\
\text { фінансово-економічної безпеки } \\
\text { підприємства та їх належної реалізації. } \\
\text { - контроль за реалізацією прийнятих } \\
\text { управлінських рішень у сфері фінансово- } \\
\text { економічної безпеки підприємства. }\end{array}$ \\
\hline
\end{tabular}


Продовження таблиці 1

\begin{tabular}{|c|c|c|}
\hline методи & $\begin{array}{l}\text { - фінансове прогнозування; } \\
\text { - фінансове планування; } \\
\text { - фінансове регулювання; } \\
\text { - фінансовий контроль; } \\
\text { - самофінансування; } \\
\text { - інвестування; } \\
\text { - трансфертні операції. }\end{array}$ & $\begin{array}{l}\text { - організаційні (прямий вплив на об’єкт } \\
\text { управління через використання } \\
\text { адміністративної влади та примусу); } \\
\text { - економічні (непрямий вплив на об'єкт); } \\
\text { - управління через економічні інтереси } \\
\text { шляхом матеріального стимулювання); } \\
\text { - соціально-психологічні (базуються на } \\
\text { закономірностях функціонування людської } \\
\text { психіки, впливають на мотиви соціальної } \\
\text { поведінки людини, включають різноманітні } \\
\text { засоби соціального орієнтування та } \\
\text { регулювання, групової динаміки, } \\
\text { вирішення конфліктних ситуацій). }\end{array}$ \\
\hline Важелі & $\begin{array}{ll}\text { - } & \text { ставка оподаткування; } \\
\text { - } & \text { рівень резервування; } \\
\text { - } & \text { ставка рефінансування НБУ; } \\
\text { - } & \text { валютний курс. }\end{array}$ & $\begin{array}{l}\text { - структура капіталу; } \\
\text { - операційний важіль; } \\
\text { - фінансовий важіль; } \\
\text { - структура витрат; } \\
\text { - норми і нормативи. }\end{array}$ \\
\hline Інстру-менти & $\begin{array}{ll}\text { - } & \text { податки; } \\
\text { - } & \text { облікова ставка; } \\
\text { - } & \text { трансферти; } \\
\text { - } & \text { субсидії; } \\
\text { - } & \text { пільги. }\end{array}$ & $\begin{array}{l}\text { - похідні цінні папери; } \\
\text { - банківські акцепти; } \\
\text { - комерційні векселі; } \\
\text { - зворотні вимоги про викуп цінних } \\
\text { паперів; } \\
\text { - страхування. }\end{array}$ \\
\hline
\end{tabular}

* Джерело: складено авторами.

Таким чином, чітке виділення компонентного складу механізму управління фінансовою безпекою створює основу для формування ефективної системи менеджменту фінансової безпеки на всіх рівнях фінансових відносин.

У рамках дослідження [2] встановлено, що механізм забезпечення фінансової безпеки на мікрорівні являє собою сукупність чітко визначених дій суб' єктів забезпечення фінансової безпеки по створенню надійних умов гарантування захисту об'єкту фінансової безпеки від негативного впливу внутрішніх і зовнішніх загроз. Дії суб'єктів фінансової безпеки можуть містити в собі набір організаційних, фінансових та правових засобів впливу на об'єкти фінансової безпеки, спрямованих на своєчасне виявлення, попередження, нейтралізацію і ліквідацію загроз фінансовій безпеці на як макро-, так і мікрорівні. Розробка такого механізму повинна базуватися на визначенні цілей, завдань, функцій і принципів забезпечення фінансової безпеки та використанні відповідного інструментарію (методів, важелів, форм, засобів забезпечення) для досягнення основної мети системи фінансової безпеки.

Що стосується загального механізму управління фінансовою безпекою, то тут необхідно підкреслити важливість забезпечення реалізації принципу гнучкості і адаптивності системи фінансової безпеки. Адаптивне управління в умовах фінансової кризи повинно стати основним напрямком вдосконалення управлінської діяльності, який повинен забезпечувати не тільки вирішення проблем, що стосуються питань фінансування поточної діяльності, а також актуально змінних завдань виживання в конкурентній боротьбі і підтримки своєї фінансово-економічної безпеки. Адаптивне управління акумулює знання про стан і розвиток системи управління, методи й інструменти його застосування в системних об'єктах, дозволяє перейти від емпіризму в теорії і практиці управління до професіоналізму діяльності менеджерів, тобто до науково обгрунтованого виконання управлінської діяльності.

У загальносистемному плані адаптація являє собою здатність економічної системи виявити цілеспрямовану пристосовану поведінку в сформованих середовищах, а також сам процес такого пристосування. Або, іншими словами, це пристосування економічної системи та її окремих суб'єктів до мінливих умов зовнішнього середовища, яке включає і процес, і здатність до такого пристосування. Система вважається адаптивною, якщо здатна пристосовуватися до раптових змін внутрішніх і зовнішніх умов.

3 терміном «адаптація» пов'язане поняття адаптивного управління. Для розкриття змісту цього поняття доречно виходити із сутності трьох типів управління, які використовуються при моделюванні процесів управління - відкрите (розімкнуте), закрите (замкнуте) та адаптивне [33]. Відкрите управління передбачає наявність 
цілі та здійснення заходів для досягнення цієї цілі, без зворотного зв'язку. При відхиленні результату від запланованого проводиться аналіз, який пояснює причини відхилення, але не ставить завдання змінити що-небудь в управлінні. Другий тип - замкнуте управління (управління зі зворотним зв'язком) - передбачає можливість змінювати управління залежно від його впливу на кінцевий результат.

Адаптивне управління ${ }^{l}$ відрізняється від замкнутого наявністю моделі керованого об'єкта, в якій прогнозуються можливі наслідки управління. Правильна реакція можлива лише при побудові максимально точної моделі поведінки об'єкта, яка адекватно відображає середовище функціонування i сам об'єкт управління. Проте, максимально точну модель об'єкта не завжди можливо сконструювати у зв'язку 3 відсутністю повної достовірної інформації, наявності непередбачуваних змінних зовнішніх впливів тощо. У фінансовому просторі часто характерною $є$ ситуація, коли наше знання про об'єкт управління і про середовище, в якій він функціонує, $є$ недостатньо повним, а потрібні для прийняття управлінських рішень масиви інформації лише частково визначені. Відома лише приналежність об'єкта до деякого класу станів. Метою управлінської діяльності в такому випадку буде досягнення оптимальної поведінки об'єкта, що виражається у вигляді послідовності певних станів. Необхідно знайти алгоритм управління (адаптивний регулятор), що забезпечує досягнення мети за кінцеве число управляючих впливів.

Основна властивість адаптивних систем реалізація мети управління в умовах недетермінованого зовнішнього середовища i мінливих параметрів об'єкта. Таким чином, адаптивне управління - це вибір оптимального способу досягнення мети, це спосіб управління, при якому зберігаються незмінними цільові показники, а поточні, короткострокові i середньострокові плани і бюджети за наявності відхилень можуть бути скориговані. 3 організаційної точки зору адаптивне управління можна розглядати як рефлексивно самоорганізовану систему, в якій в результаті оцінювання змін параметрів зовнішнього i внутрішнього середовища відбувається відповідне підстроювання організаційної структури і системи менеджменту в цілому, що забезпечує функціонування об'єкта управління.

Актуалізація проблем забезпечення фінансової безпеки як на макро-, так i на мікрорівнях в сучасних умовах розвитку економіки України вимагає врахування при побудові системи управління принципу адаптивності та рефлективності. Адаптивне управління $є$ необхідним елементом такої системи, адже воно створює передумови для досягнення стратегічних цілей шляхом своєчасного реагування на зміни у зовнішньому та внутрішньому середовищах i внесення відповідних коректив у стратегію розвитку, а також поточні та оперативні плани.

Адаптивне фінансове управління вимагає наявності трьох інструментів [5]:

1) інструменту прогнозування, щоб можна було оперативно оцінювати, до яких результатів (наприклад, до яких фінансових показників) призведе поточний стан справ i поточні економічні тенденції;

2) інструменту коригування планів, щоб можна було оперативно змінювати застарілі плани, якщо вони вже не забезпечують мети;

3) «зворотного зв'язку» 3 поточними результатами діяльності.

Адаптивне управління дозволяє прогнозувати вплив управлінських рішень на кінцевий результат діяльності, адекватно коригувати поточні бюджети, форми та способи захисту інтересів при зміні умов функціонування суб'єктів господарювання внаслідок впливу зовнішніх факторів та, в кінцевому рахунку, забезпечити досягнення довгострокових цілей безпечного розвитку. Схематично процес управління фінансовою безпекою з урахуванням принципу адаптивності можна представити у такому вигляді (рис.1).

Управління фінансовою безпекою на основі принципу адаптивності передбачає функцію оцінювання результативності кроків управління в умовах невизначеності зовнішніх впливів. При цьому вважаються відомими основні характеристики множини можливих негативних впливів зовнішнього і внутрішнього середовища на рівень фінансової безпеки та їх параметри, але невідомі час і послідовність їх реалізації.

Управління фінансовою безпеки складається з двох блоків - блоку регулювання та блоку адаптації. В блоку регулювання суть управління зводиться до вимірювання вхідних параметрів (як регульованих, так і нерегульова-

\footnotetext{
${ }^{1}$ Проблема адаптивного управління в системі

фінансової безпеки розглянута автором у праці [4].
} 


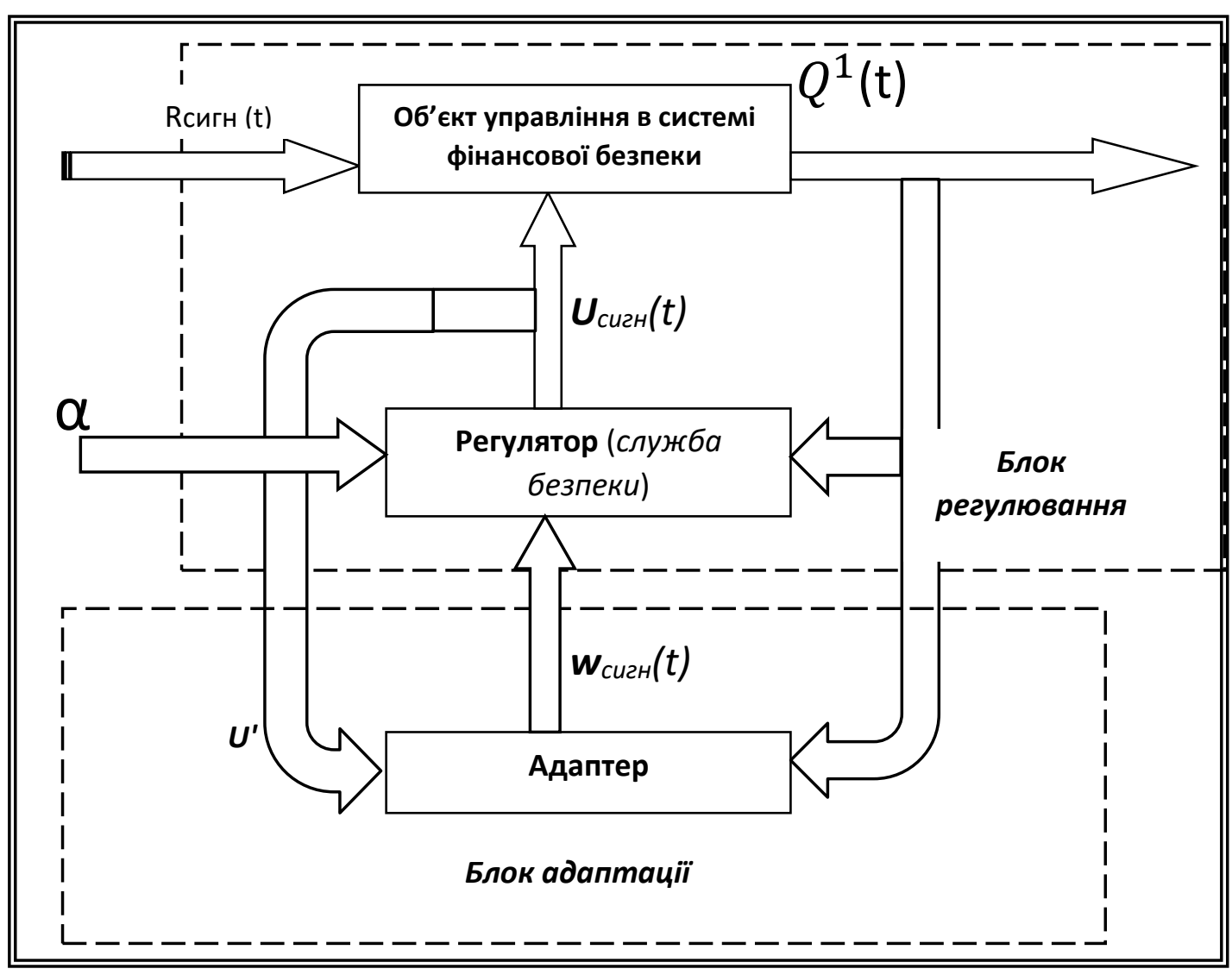

$R_{\text {сигн }}(t)$ - вхідні інформаційні потоки (впливи зовнішнього середовища);

$Q^{l}(t)$ - показник захищеності (інтегральний показник рівня фінансової безпеки);

$U_{\text {сигн }}(t)$ - управляючі дії;

$U^{\prime}$ - управлінські рішення, які потребують адаптації;

$w_{\text {сигн }}(t)$ - адаптовані управлінські рішення;

$\alpha$ - необхідне значення показника захищеності.

\section{Рис.1. Управління фінансовою безпекою з урахуванням принципу адаптивності*}

* Джерело: адаптовано на основі [6].

них) та оцінки їх впливу на рівень фінансової безпеки. Вихідні параметри об'єкта управління вказують на ефективність системи ФБ. Регулятору надається бажане значення $\alpha$ показника захищеності i він забезпечує досягнення цілі. Припущення про відсутність змін параметрів негативних впливів визначає доцільність досягнення мети управління для прогнозованого значення $\mathrm{Q}^{1}(\mathrm{t})$.

I на макрорівні i на мікро-рівні алгоритм адаптації повинен бути спрямований на зміну вектору параметрів управління таким чином, щоб забезпечити досягнення цілі управління при невідомих значеннях параметрів інформаційних впливів. В основі його лежить управління алгоритмом прогнозування. Наявність несприятливих факторів визначається на основі перевищення вхідного сигналу $r_{j}$ гранично допустимого значення $r_{\text {крum, при цьому }}$ дестабілізуючий фактор нейтралізується (попереджається) і вирішується задача адаптації системи управління фінансовою безпекою підприємства до нових умов.

На мікро-рівні механізм адаптації до змін зовнішнього та внутрішнього середовища відіграє важливу роль у досягненні основної мети. Проте, слід зауважити, що адаптацію, як механізм регулювання в системі фінансової безпеки, який дозволяє підприємству забезпечувати стабільний розвиток незалежно від впливу зовнішніх чинників, слід використовувати у тому випадку, якщо вплив зовнішніх чинників не $є$ значним і не загрожує існуванню економічного суб'єкта.

Результати аналізу різних науково-технічних напрямів, в рамках яких на даний час проводяться дослідження окремих аспектів адаптивного управління на рівні корпоративних підприємств, дозволили виділити наступні основні вимоги, які пред'являються до процесу формування i 
функціонування систем адаптивного управління [7]:

коректність обліку складного просторово-часового причинно-наслідкового характеру взаємодії елементів, які складають внутрішнє середовище;

постійне відстежування адекватності алгоритмів прийняття управлінських рішень умовам функціонування суб'єкта фінансових відносин;

- надання переваги гнучкості та
варіативності алгоритмів прийняття управлінських рішень та реалізації управлінських впливів, а не постійній зміні організаційної структури; необхідність

використання

спеціального математичного (зокрема, формально-логічного) апарату для розв'язання задач оптимального регулювання та прогнозування динаміки розвитку суб'єкта фінансових відносин.

Розробка сучасних моделей адаптивного управління фінансовою безпекою як на макрорівні (держави), так і мікро-рівні (корпорацій та фірм) потребує розвитку та застосування відповідного комплексу інструментів та підходів мікроекономіки, теорії організацій, еволюційної економіки, теорії економічних інститутів, теорій фінансової динаміки. Особливо значимими $є$ питання, пов'язані з аналізом форм адаптації, розкриття напрямків необхідних змін, аналіз підсумків процесу адаптації, визначення глибини якісних зрушень у фінансовій системі досліджуваних суб'єктів.

Труднощі прогнозування станів зовнішнього середовища та характеристик зовнішніх вхідних потоків можна враховувати створенням деяких механізмів адаптивної зміни i структури організації, i параметрів регулювання організаційних процесів та фінансових механізмів у відповідності із зміною обставин та характеристик потоків викликів та завдань. 3 цією метою потрібно будувати гнучкі структури та гнучкі методи регулювання процесів та функцій. Така організація може називатися адаптивною. Адаптивна організація $є$ частинним випадком адаптивних систем [8, С.272].

На макрорівні така адаптивна організація системи фінансової безпеки повинна забезпечуватися насамперед адаптивною фінансовою політикою держави та адаптацією фінансових механізмів державного бюджету, адаптацією механізмів регіональних бюджетів та бюджетів об'єднаних територіальних громад до викликів пандемічної кризи та загроз кризи глобальної фінансової системи пов'язаних протистоянням інтересів «фінансових гігантів» КНР та США.

Аналіз рівня окремих складових фінансової безпеки держави, зокрема щодо банківських та небанківських ринків фінансових послуг, у цілому підтверджує ефективність впродовж останніх років політики НБУ, яка була спрямована на підвищення капіталізації діючих комерційних банків та істотне зменшення кількості неефективних банківських установ. 3 2020 року внаслідок реформування системи державного нагляду та передачі функцій контролю за страховим ринком НБУ, регулятором зафіксовано ряд проблем, пов'язаних 3 діяльністю страховиків, які стосуються проблеми оцінки їх платоспроможності, недосконалості їх бізнесмоделей, операційної неефективності тощо, які негативно впливають на рівень їх фінансової безпеки [9]. Це свідчить, що виклики результативного застосування принципу адаптивності у певних сферах має місце на рівні держави. Але необхідно відмітити, що рівень інституціонального розвитку фінансового ринку, насамперед ринку капіталів, як основних рефлексивних адаптивних регуляторів макрорівня абсолютно недостатній.

Труднощі результативного застосування принципу адаптивності як на макрорівні так і на макрорівні пов'язані $з$ тим, що в «адаптивній» постановці задача оптимального управління фінансовою безпекою повинна розв'язуватися в чотири моделі-етапи: модель-етап планування (регулювання) оптимального стану безпеки, імітаційна модель-етап формування процесу змін на основі включення оцінки ризиків не впроваджувати зміни, внутрішній (імітаційний) адаптер параметрів функціонування суб'єкта фінансових ринків та бюджетних відносин оцінки відповідності, зовнішній (об'єктний) адаптер приведення показників фінансової діяльності суб'єкта до вимог різко зміненої фінансової ситуації. Зовнішній адаптер на основі власних характеристик та завдань оптимізації структури фінансових можливостей об'єкту і зовнішнього середовища вибирає тип та характеристики задачі планування, і також вибирає імітаційну модель запланованого процесу підвищення рівня фінансової безпеки Тим самим покладає початок структурної адаптації системи управління. Далі, за результатами виконання планів попередніх періодів і врахування досвіду відгуку на впливизбурення, адаптер налаштовує параметри в моделі планування (регулювання) та в імітаційних моделях об'єкту, середовища та системи регулювання. На основі цих часткових 
імітаційних моделей будується загальна імітаційна модель за якою здійснюється реалізація оновленого фінансового плану. Якщо план $з$ врахуванням можливостей його реалізації $\epsilon$ прийнятним, то він приймається до виконання. В іншому випадку знову включається внутрішній адаптер, який використовуючи результати імітаційного процесу та процесу звірки викликиреакції налаштовує параметри моделі планування і моделі регулювання. Робота схеми адаптивного управління починається спочатку, стартуючи від проблеми перерахунку «плану фінансових заходів» при нових параметрах цілей фінансової безпеки.

Водночас, стосовно мікро-рівня, а саме рівня корпоративних підприємств, то науково обгрунтовані моделі управління, що вимагають залучення складного математичного апарату i значних масивів часових рядів по цілому ряду параметрів, що характеризують вплив факторів зовнішнього і внутрішнього середовищ на рівень фінансової безпеки, до теперішнього часу не отримали достатнього поширення. Основними причинами, що ускладнюють практичне використання теоретичних моделей управління фінансовою безпекою , є достатньо високий рівень інформаційної закритості («непрозорості») більшості вітчизняних корпоративних підприємств. Тобто спостерігається фактична відсутність необхідної статистичної інформації у зв'язку 3 нерозвиненістю облікової та інформаційно-аналітичної сфер діяльності; укорінена звичка багатьох керівників розраховувати при виробленні управлінських рішень тільки на свої власні аналітичні здібності, досвід та інтуїцію, явна недооцінка складності задачі оптимального управління корпоративним підприємством; низький рівень програмнотехнологічного забезпечення, орієнтація на вирішення окремих завдань управління (наприклад, автоматизацію бухгалтерського обліку) часто на шкоду комплексним рішенням у сфері управління.

\section{Висновки i перспективи подальших} досліджень. Таким чином, управління фінансовою безпекою як на макро-, так і на мікрорівнях повинно здійснюватися на основі: принципу адаптивності; вибору адекватного алгоритму адаптивного управління; застосування ефективних інструментів механізму забезпечення фінансової безпеки. У той же час важливо відзначити, що якість управління відкритою будьякою соціально-економічною системою значною мірою залежить від ефективності використання інформації, яка може бути отримана шляхом оцінки та обробки вхідних параметрів, що характеризують динаміку факторів впливу зовнішнього і внутрішнього середовища.

Вирішення завдання своєчасного аналізу i прийняття на його основі результатів адекватних управлінських рішень у сфері фінансової безпеки може бути забезпечено завдяки використанню математичних методів і прийомів оптимального стохастичного регулювання. При цьому ефективність функціонування суб'єкту фінансових відносин підвищується переважно за рахунок раціоналізації алгоритмів прийняття рішень, а не дорогих, часто болючих процедур перебудови організаційної структури або зміни нераціональної структури активів чи зміни загальної парадигми господарювання.

\section{ПЕРЕЛІК ВИКОРИСТАНИХ ДЖЕРЕЛ}

1. Пойда-Носик Н.Н. Управління фінансовою безпекою як специфічний напрям менеджменту. Формування стратегії соціально-економічного розвитку підприємницьких структур в Україні: Матеріали Всеукраїнської науково-практичної інтернет-конференції (м. Львів, 19-21 листопада 2015 р.). Львів: Укр. акад. друкарства, 2015. C.117-120.

2. Пойда-Носик Н. Н. Фінансова безпека акціонерних товариств: теоретико-методологічний та практичний аспекти системного підходу : монографія. Чернігів, 2020. 306 с.

3. Карпов Л. Е. Юдин В.Н. Адаптивное управление по прецедентам, основанное на классификации состояний управляемых объектов. Труды Института системного программирования PAH. URL: http://citforum.ru/consulting/BI/karpov/ (дата звернення 14.03.2021).

4. Пойда-Носик Н.Н. Адаптивне управління в системі забезпечення фінансової безпеки корпоративного підприємства. Інформаційна та економічна безпека (INFECO-2015): матеріали II Міжнародної науковопрактичної інтернет-конференції (м. Харків, 21-22 травня 2015 р.). Харків: ХІБС УБС НБУ, 2015. 1 електрон. опт. диск (CD-ROM).

5. Адаптивное управление: «продвигать» предприятие к цели. Рациональное управление предприятием. 2009. №2. C.52-55.

6. Данеев А.В., Воробьев А.А., Лебедев Д.М. Алгоритмы управления сложными организационно-техническими системами. Известия Иркутской государственной экономической академии. 2010. №4(72). С.83-86. 
7. Аубакирова Г.M. Адаптивный поход к управлению промышленным предприятием. URL: http://www.rusnauka.com/DN2006/Economics/10_aubakirova.doc.htm (дата звернення 12.03.2021).

8. Черленяк I.I. Синергетичні моделі оптимізації системи державного управління: монографія. Ужгород: Лipa, 2010. $656 \mathrm{c}$.

9. Майбутнє регулювання ринку страхування в Україні: біла книга. URL: https://bank.gov.ua/ua/news/all/bilakniga-maybutnye-regulyuvannya-rinku-strahuvannya (дата звернення 14.03.2021).

\section{REFERENCES}

1. Poyda-Nosyk, N.N. (2015). Upravlinnja finansovoju bezpekoju jak specyfichnyj naprjam menedzhmentu [Financial security management as a specific area of management]. Proceedings from: Vseukrajinsjka naukovo-praktychna internet-konferencija «Formuvannja strateghiji socialjno-ekonomichnogho rozvytku pidpryjemnycjkykh struktur v Ukrajini» - the All-Ukrainian scientific-practical Internet conference «Formation of the strategy of socio-economic development of business structures in Ukraine». (pp. 117-120). Ljviv: Ukr. akad. drukarstva [in Ukrainian].

2. Poyda-Nosyk, N.N. (2020). Finansova bezpeka akcionernykh tovarystv: teoretyko-metodologhichnyj ta praktychnyj aspekty systemnogho pidkhodu : monoghrafija [Financial security of joint stock companies: theoretical, methodological and practical aspects of a systematic approach: a monograph]. Chernighiv [in Ukrainian].

3. Karpov, L.E. \& Yudin, V.N. (n.d.). Adaptivnoe upravlenie po pretsedentam, osnovannoe na klassifikatsii sostoyaniy upravlyaemykh objektov [Adaptive case management based on the classification of states of managed objects]. Proceedings from: Institut sistemnogo programmirovaniya RAN - the Institute of System Programming of the RUS. Retrieved from: http://citforum.ru/consulting/BI/karpov/ [in Russian].

4. Poyda-Nosyk, N.N. (2015). Adaptyvne upravlinnja v systemi zabezpechennja finansovoji bezpeky korporatyvnogho pidpryjemstva [Adaptive management in the system of financial security of a corporate enterprise]. Proceedings from: Informacijna ta ekonomichna bezpeka (INFECO-2015) - nformation and economic security (INFECO-2015). Kharkiv: KhIBS UBS NBU [in Ukrainian].

5. Adaptivnoe upravlenie: «prodvigat'» predpriyatie $\mathrm{k}$ tseli [Adaptive management: "promote" the company to the goal]. (2009). Ratsional'noe upravlenie predpriyatiem - Rational management of an enterprise, № 2, 52-55 [in Ukrainian].

6. Daneev, A.V., \& Vorobjev, A.A., \& Lebedev, D.M. (2010). Algoritmy upravleniya slozhnymi organizatsionnotekhnicheskimi sistemami [Algorithms for managing complex organizational and technical systems]. Izvestiya Irkutskoy gosudarstvennoy ekonomicheskoy akademii - Proceedings of the Irkutsk State Economic Academy, № 4 (72), 83-86 [in Russian].

7. Aubakirova, G.M. (n.d.). Adaptivnyy pokhod k upravleniyu promyshlennym predpriyatiem [Adaptive approach to the management of an industrial enterprise]. Retrieved from: http://www.rusnauka.com/DN2006/Economics/10_aubakirova.doc.htm [in Russian].

8. Cherleniak, I.I. (2010). Synerhetychni modeli optymizatsii systemy derzhavnoho upravlinnia: monohrafiia [Synergetic models of public administration system optimization: a monograph]. Uzhhorod: Lira. [in Ukrainian].

9. Maibutnie rehuliuvannia rynku strakhuvannia v Ukraini: bila knyha [Future regulation of the insurance market in Ukraine: the white book]. (n.d.). Retrieved from: https://bank.gov.ua/ua/news/all/bila-kniga-maybutnyeregulyuvannya-rinku-strahuvannya [in Ukrainian].

Отримано 26.02.2021 